\title{
Pembelajaran Tarikh Berbasis Kearifan Lokal Pada Kelas IX di SMP Muhammadiyah 3 Yogyakarta
}

\section{Lussita Jeni Nindika}

Universitas Muhammadiyah Yogyakarta

Email : Lussita.jeni.2016@fai.umy.ac.id

Fajar Rachmadhani

Universitas Muhammadiyah Yogyakarta

Email : fajarrachmadhani@umy.ac.id

\begin{tabular}{|c|c|}
\hline \multirow{2}{*}{$\begin{array}{l}\text { Submission } \\
\text { Track: }\end{array}$} & Abstract \\
\hline & \\
\hline Received: & $\begin{array}{l}\text { This study aims to analyze: (1) the implementation of Tarikh (bistory) learning based on local } \\
\text { wisdom, (2) the supporting and inhibiting factors of Tarikh learning based on local wisdom in }\end{array}$ \\
\hline 3 februari 2020 & $\begin{array}{l}\text { Class IX at SMP (Junior High School) Mubammadiyah } 3 \text { Yogyakarta The type of this } \\
\text { research approach is a descriptive qualitative approach. The subjects of this research were the }\end{array}$ \\
\hline Final Revision: & $\begin{array}{l}\text { activities of teachers and students during the Tarikh learning process. The object of this } \\
\text { research was local wisdom in Tarikh learning method in Class IX at SMP Mubammadivah } 3\end{array}$ \\
\hline 15 Maret 2020 & Yogyakarta. Data were obtained through observation of learning activities, interviews, field \\
\hline Available online: & $\begin{array}{l}\text { notes, and documentation in the form of pictures of learning activities. Data analysis } \\
\text { techniques included the stages of data reduction, data presentation, and conclusion. The validity }\end{array}$ \\
\hline 25 Maret 2020 & $\begin{array}{l}\text { of the data was obtained through triangulation. The results of this study indicate things as } \\
\text { follows: (1) the implementation of Tarikh learning in Class IX at SMP Mubammadiyah } 3\end{array}$ \\
\hline Corresponding & $\begin{array}{l}\text { Yogyakarta is in accordance with the local wisdom of the Special Region of Yogyakarta, (2) } \\
\text { the supporting factors for the implementation of Tarikh learning based on local wisdom in }\end{array}$ \\
\hline Author: & $\begin{array}{l}\text { Class IX at SMP Mubammadiyah } 3 \text { Yogyakarta are adequate learning facility and students' } \\
\text { awareness of the importance of preserving history and culture, while the inbibiting factors for }\end{array}$ \\
\hline Name \& E-mail Address & implementing Tarikh learning based on local wisdom in Class IX at SMP Mubammadiyah 3 \\
\hline Lussita Jeni Nindika & $\begin{array}{l}\text { motivation. } \\
\text { Keywords: Tarikh learning, local wisdom. }\end{array}$ \\
\hline
\end{tabular}

lussita.jeni.2016@fai.umy.ac.id

Fajar Rachmadhani

fajarrachmadhani@umy.ac.id

\section{Abstrak}

Penelitian ini bertujuan untuk menganalisis: (1) pelaksanaan pembelajaran Tarikh berbasis kearifan lokal, (2) faktor pendukung dan penghambat pembelajaran Tarikh berbasis kearifan lokal pada kelas IX di SMP Muhammadiyah 3 Yogyakarta. Jenis pendekatan penelitian ini adalah pendekatan deskriptif kualitatif. Subjek penelitian ini adalah aktivitas guru dan siswa saat proses pembelajaran Tarikh. Objek penelitian ini adalah kearifan lokal dalam metode pembelajaran Tarikh pada kelas IX di SMP Muhammadiyah Yogyakarta. Data diperoleh melalui observasi kegiatan pembelajaran, wawancara, catatan lapangan, dan dokumentasi berupa gambar kegiatan pembelajaran. Teknik analisis data meliputi tahapan reduksi data, penyajian data, dan kesimpulan. Keabsahan data diperoleh melalui triangulasi. Hasil penelitian menunjukkan hal - hal sebagai berikut: (1) pelaksanaan pembelajaran Tarikh pada kelas IX di SMP Muhammadiyah 3 Yogyakarta sesuai dengan kearifan lokal masyarakat Daerah Istimewa Yogyakarta, (2) faktor pendukung pelaksanaan Tarikh berbasis kearifan lokal pada kelas IX di SMP Muhammadiyah 3 Yogyakarta adalah fasilitas pembelajaran yang memadahi dan kesadaran siswa akan pentingnya menjaga sejarah dan budaya, faktor penghambat pelaksanaan pembelajaran Tarikh berbasis kearifan lokal pada kelas IX di SMP Muhammadiyah 3 Yogyakarta adalah suasana kelas, banyaknya materi pelajaran, dan kurangnya motivasi belajar siswa.

Kata Kunci : Pembelajaran Tarikh, Kearifan Lokal 


\section{PENDAHULUAN}

Kearifan lokal Daerah Istimewa Yogyakarta memegang peranan penting bagi tolok ukur warga Yogyakarta dalam bermasyarakat. Kearifan lokal merupakan alat untuk melestarikan norma dan adat istiadat. Demikian dalam Islam, perkembangan Islam tidak terpisahkan dari basis kearifan tradisi maupun budaya setempat. Sebagian ahli mengidentifikasi proses Islamsasi di Indonesia sebagai adhesi, atau sebagai lokalisasi agama mengingat budaya masyarakat lokal dinilai kontributif dalam proses menerima pengaruh luar, menyerap, dan menyatakan kembali unsur - unsur luar itu dengan cara menempanya hingga sesuai dengan pandangan hidup masyarakat lokal dan mengambilnya sebagai bagian dari budayanya (Arif, 2015).

Dalam pembelajaran, kearifan lokal dapat dikontekstualisasikan guru melalui mata pelajaran yang diberikan. Dengan adanya kearifan lokal, siswa diharapkan untuk dapat menjaga nilai - nilai serta budaya yang ada. Kearifan lokal dapat tertanam pada materi pelajaran sebagai alternatif strategi pembelajaran. Salah satu cara guru untuk melestarikan budaya dan adat istiadat dapat dilakukan dengan memberikan pembelajaran yang berbasis kearifan lokal. Pembelajaran berbasis kearifan lokal diharapkan mampu menumbuhkan rasa toleransi dan menumbuhkan rasa hormat kepada nilai - nilai kearifan lokal agar tetap terjaga.

Pembelajaran berbasis kearifan lokal dapat dilaksanakan dalam pembelajaran Tarikh. Pembelajaran Tarikh berbasis kearifan lokal mendapatkan peran penting bagi sekolah yang berbasis agama Islam. Tarikh merupakan salah satu mata pelajaran Al - Islam, Kemuhammadiyahan, dan Bahasa Arab atau disingkat dengan ISMUBA, didalamnya terdapat pemahaman terhadap sejarah Islam yang masih relevan sampai saat ini. Dijelaskan dalam Peraturan Menteri Agama No.2 Tahun 2008 bahwa mata pelajaran Tarikh memiliki kontribusi dalam mengembangkan motivasi kepada peserta didik untuk mengenal, memahami, menghayati sejarah Islam, yang mengandung nilai nilai kearifan yang dapat digunakan untuk melatih kecerdasan membentuk sikap, watak, dan kepribadian peserta didik. Banyaknya kisah - kisah yang ada dalam $\mathrm{Al}$ - Qur'an dapat dijadikan sebagai pembelajaran yang selanjutnya dipergunakan sebagai pedoman hidup bagi umat muslim, yang tertulis dalam surat Hud; 120.

Pelajaran Pendidikan Al-Islam, Kemuhammadiyahan dan Bahasa Arab atau yang disingkat dengan ISMUBA mencakup beberapa mata pelajaran wajib yang harus ditempuh pelajar Muhammadiyah. Dari beberapa mata pelajaran ISMUBA tersebut, Tarikh dianggap salah satu mata pelajaran yang sulit. Dalam pembelajaran Tarikh siswa dituntut untuk mampu menghafal peristiwaperistiwa hingga tokoh pada masa tersebut. Anggapan sulit itu menjadikan minat belajar siswa terhadap mata pelajaran Tarikh kurang. Di samping itu, penyampaian pembelajaran Tarikh yang biasanya di dominasi oleh metode ceramah menjadikan semakin berkurangnya antusias mereka terhadap pembelajaran Tarikh. Untuk itu siswa memerlukan guru sebagai fasilitator sekaligus motivator yang mampu menjadikan pembelajaran Tarikh lebih menyenangkan.

Guru dituntut untuk dapat menciptakan pembelajaran yang efektif dan efisien. Selain itu, guru dituntut untuk lebih kreatif perihal menentukan strategi pembelajaran. Salah satu upaya yang mampu guru ambil dalam pelaksanaan 
kegiatan pembelajaran yakni dengan menyertakan kearifan lokal sebagai strategi pembelajaran. Dalam pembelajaran Tarikh berbasis kearifan lokal, pelajaran akan mudah diterima siswa ketika siswa faham dengan lingkungan belajarnya. Kearifan lokal dimaknai sebagai jembatan untuk menggambarkan sejarah Islam dengan fenomena saat ini.

Kearifan lokal pada suatu daerah masih kurang dalam implementasinya, terlebih dalam pembelajaran. Misalnya pada materi Tarikh tentang sejarah peradaban Islam, yang seharusnya bisa dikontekstualisasikan dengan kearifan lokal Daerah Istimewa Yogyakarta. Dampaknya pelajaran akan sulit difahami dan siswa akan menjadi kurang atusias saat menerima budaya Arab yang berbeda dengan budaya yang ada di lingkungannya.

Karakteristik siswa yang berbeda dan kondisi siswa yang heterogen menjadikan guru harus mampu mengatasi permasalahan dalam proses pembelajaran. Sayangnya, masih banyak ditemui dalam pembelajaran Tarikh, guru menggunakan metode pembelajaran yang kurang menarik. Guru masih terlalu nyaman untuk menggunakan metode dan strategi pembelajaran terdahulu.

Berdasarkan hasil observasi kelas IX SMP Muhammadiyah 3 Yogyakarta pada tanggal 16 September 2019, diketahui bahwa masih dimungkinkan penggunaan pelaksanaan pembelajaran berbasis kearifan lokal di SMP Muhammadiyah 3 Yogyakarta. Pada obervasi yang telah dilakukan, saya mendapati guru dominan pada pembelajaran dengan metode ceramah. Dengan metode tersebut siswa menjadi mudah bosan dengan materi yang disampaikan guru. Siswa menjadi kurang menanamkan nilai - nilai kearifan dan menjadi pasif atas pelajaran yang harus diterimanya.

Berdasarkan latar belakang tersebut, maka perlu dilakukan peneitian tentang pelaksanaan pembelajaran berbasis kearifan lokal pada kelas IX di SMP Muhammadiyah 3 Yogyakarta. Alasan yang mendasari pemilihan lokasi penelitian yaitu dikarenakan SMP Muhammadiyah Yogyakarta merupakan sekolah yang memiliki program kelas IT dan Bilingual. SMP Muhammadiyah 3 Yogyakarta sebagai salah satu sekolah Muhammadiyah Yogyakarta yang unggul dalam bidang akademis mejadikan sekolah tersebut sangat menarik untuk saya teliti. Hal tersebut mendorong penulis untuk melakukan penelitian lebih mendalam mengenai pembelajaran Tarikh berbasis kearifan lokal pada kelas IX di SMP Muhammadiyah 3 Yogyakarta.

\section{METODE PENELITIAN}

Pendekatan yang digunakan dalam penelitian ini adalah kualitatif deskriptif. Menurut Akif Khilmiyah (Khilmiyah, 2016) data yang dikumpulkan dalam penelitian kualitatif deskriptif berupa kata - kata dan gambar, bukan berupa angka. Hal tersebut disebabkan oleh penerapan metode kualitatif. Selain itu, data yang telah dikumpulkan dapat dijadikan sebagai kunci terhadap apa yang sudah diteliti. Maka dari itu, hasil penelitian berisikan kutipan - kutipan data untuk memberi gambaran penyajian hasil penelitian tersebut. Data yang diperoleh berasal dari naskah wawancara, catatan lapangan, foto, video, dokumen pribadi, memo atau catatan, dan dokumen resmi lainnya. Pada penulisan hasil penelitian demikian, peneliti menganalisis data yang sangat banyak dan sejauh mungkin dalam bentuk aslinya. 
Data penelitian berupa hasil wawancara, dokumentasi, dan dokumen pembelajaran akan didapatkan pada observasi lapangan di SMP Muhammadiyah 3 Yogyakarta. Peneliti akan menganalisis data dengan sistematis berdasarkan fenomena yang terjadi dalam pelaksanaan pembelajaran Tarikh pada kelas IX di SMP Muhammadiyah 3 Yogyakarta. Analisis data berupa berbentuk deskriptif untuk menjelaskan secara keseluruhan hasil penelitian di SMP Muhammadiyah 3 Yogyakarta.

Penelitian kualitatif, pengumpulan data dilakukan pada natural setting (kondisi yang alamiah), sumber data primer, dan teknik pengumpulan data lebih banyak pada observasi berperanserta (participan observation), wawancara mendalam (in depth interview) dan dokumentasi (Sugiyono, 2010).

Kredibilitas terkait pengelolaan data, peneliti menggunakan uji triangulasi. Pada teknik pengumpulan data, triangulasi diartikan sebagai teknik pengumpulan data yang bersifat menggabungkan dari berbagai teknik pengumpulan data dan sumber data yang telah ada. Data berupa hasil wawancara, hasil observasi dan dokumen pendukung pembelajaran. Bila peneliti melakukan pengumpulan data dengan triangulasi, maka sebenarnya peneliti mengumpulkan data yang sekaligus menguji kredibilitas data, yaitu mengecek kredibilitas data dengan berbagai teknik pengumpulan data dan berbagai sumber data (Sugiyono, 2010).

Analisis data kualitatif dikemukakan pula oleh Miles dan Huberman bahwa aktivitas dalam analisis data kualitatif dilakukan secara interaktif dan berlangsung secara terus menerus sampai tuntas, sehingga datanya jenuh (Sugiyono, 2010). Aktivitas dalam analisis data yaitu, reduksi data, penyajian data, dan menarik kesimpulan.

Peneliti akan membahas secara menyeluruh tentang kearifan lokal sebagai strategi pembelajaran di SMP Muhammadiyah 3 Yogyakarta. Kemudian peneliti menganalisis data tersebut bertujuan untuk mendapatkan informasi secara konkrit, serta dapat melihat pelaksanaan pembelajaran berbasis kearifan lokal di SMP Muhammadiyah 3 Yogyakarta.

\section{HASIL dan PEMBAHASAN}

\section{Metode Pembelajaran Tarikh di SMP Muhammadiyah 3 Yogyakarta}

Menurut aliran behavioristik, pembelajaran merupakan usaha guru dalam membentuk perilaku siswa dengan menyediakan keadaan sekitar atau stimulus (Hamdani, 2011). Menurut Darsono dalam Hamdani aliran kognitif menjelaskan bahwa pembelajaran merupakan cara guru memberikan kesempatan kepada siswa untuk berfikir agar memahami serta mengenal sesuatu yang sedang dipelajari. Selain itu menurut Sugandi dalam Hamdani, aliran humanistik menjelaskan pembelajaran sebagai tempat pemberian kebebasan kepada siswa untuk memilih bahan pelajaran sebagai memberikan kebebasan kepada siswa untuk memilih materi pelajaran dan cara untuk mempelajarinya sesuai dengan kemampuan dan minatnya. Berdasarkah hasil penelitian, pelaksanaan pembelajaran Tarikh di SMP Muhammadiyah 3 Yogyakarta menerapkan empat metode. Masing masing metode memiliki pelaksanaan yang berbeda. Pertama, metode ceramah, metode ini biasa guru pergunakan untuk membuka pembelajaran. Kedua, metode diskusi, metode ini dipergunakan guru sebagai evaluasi, biasanya guru sajikan dengan pemberian soal yang selanjutnya siswa diskusikan 
dengan dua anggota kelompok atau lebih. Ketiga, metode tanya jawab, metode ini biasanya dilaksanakan setelah penjelasan dengan metode ceramah maupun setelah diskusi kelompok sebagai umpan balik dan penguatan dalam pembelajaran. Keempat, metode demonstrasi, metode yang dilakukan untuk memaparkan hasil pemikirannya maupun hasil diskusi kelompok.

Peneliti juga melakukan wawancara kepada beberapa siswa terkait dengan metode pembelajaran yang dipakai guru dalam pembelajaran Tarikh. Berdasarkan hasil wawancara, peneliti menyimpulkan bahwa guru masih dominan menggunakan metode ceramah sebagai metode pembelajaran. Perbedaan metode yang guru pergunakan disesuaikan dengan keadaan siswa demi keefektifan pembelajaran. Perlakuan tersebut guru pergunakan untuk menarik minat belajar siswa.

Tarikh sebagai salah satu mata pelajaran ISMUBA dianggap penting untuk menerapkan metode ceramah oleh guru, hal tersebut dijelaskan dalam hasil wawancara oleh Bapak Supardiyono. Berdasarkan penjelasan guru dalam hasil wawancara, peneliti menyimpulkan bahwa guru terlalu nyaman menggunakan metode ceramah sebagai metode belajar. Guru yang menganggap materi pendidikan agama Islam abstrak tidak membuat dirinya survive untuk mengkolaborasikan metode tersebut dengan menyajikan contoh contoh yang bisa didapat dari internet. Hal ini terkait dengan pembelajaran masa lampau tentang budaya Islam yang berkembang dengan metode ceramah. Namun, untuk saat ini metode tersebut akan kalah saat teknologi informasi berkembang lebih pesat dengan tidak diikuti kreatifitas guru dalam pembelajaran. Pada akhirnya pemaksimalan metode sebagai alat pembelajaran agar lebih efektif masih menjadi usaha besar bagi guru Tarikh di SMP Muhammadiyah 3 Yogyakarta.

\section{Ruang Lingkup Pembelajaran Tarikh}

Tarikh memiliki beberapa pengertian yang ditinjau dari beberapa aspek terkait. Menurut Ibrahim Al - Quraibi, pengertian Tarikh ditinjau dari makna etimologisnya berarti informasi tentang waktu (Al-Quraibi, 2009). "Aku menjelaskan waktu penulisan kitab", bahasa Arabnya adalah "Arrakhtu al-kitab wa warrakhtubu". Baik arrakhtu maupun warrakhtu adalah akar Tarikh. Tarikh merupakan disiplin ilmu yang memberikan informasi tentang perkembangan sebuah masyarakat, serta merupakan media untuk mengetahui berbagai peristiwa yang terjadi pada masa lampau, di samping itu untuk mengetahui sejauh mana perkembangan ilmu yang ada mempengaruhi masa yang akan datang.

Sejarah berasal dari bahasa Arab Syajarah yang artinya pohon. Abd Rahman As-Syakhawi juga mendefinisikan sejarah sebagai seni yang berkaitan dengan serangkaian anekdot yang berbentuk kronologi peristiwa (Mardhiyah, 2016).

Mata pelajaran tarikh merupakan mata pelajaran tambahan yang biasanya ditemukan dalam sekolah berbasis agama Islam. Misalnya Madrasah Ibtida'iyah (MI), Madrasah Tsanawiyah (MTs), Madrasah Aliyah (MA), dan sekolah - sekolah yang bernaung dalam organisasi Muhammadiyah (Ramdhani, 2014). Tarikh merupakan perkembangan kehidupan manusia terutama umat muslim dari masa ke masa dalam usaha mempertahankan ilmu agama Islam berikut akhlak serta dalam mengembangkan sistem kehidupan yang dilandasi dengan akidah (Setyawan \& 
Arumsari, 2019). Tarikh secara substansial merupakan mata pelajaran yang memiliki kontribusi dalam memberikan motivasi kepada peserta didik untuk memahami, mengenal, menghayati sejarah kebudayaan Islam, yang mengandung nilai - nilai kearifan yang dapat digunakan untuk melatih kecerdasan membentuk sikap, watak, dan kepribadian peserta didik (Rofik, 2015).

Sejarah kebudayaan Islam sebagai ruang lingkup pembelajaran Tarikh menjadikan banyak pelajaran membahas tentang budaya. Materi pelajaran Tarikh kelas IX semester gasal ini didominasi dengan materi sejarah kebudayaan Islam. Siswa banyak menjumpai budaya - budaya yang berkembang di Indonesia baik itu merupakan budaya Islam maupun produk budaya non Islam.

Penjelasan guru mengenai peran Tarikh sebagai pelajaran yang sangat melekat bagi masyarakat Indonesia dimaknai penting dalam pembelajaran untuk pelestarian budaya dan filter bagi umat Islam dalam memilah - milah budaya yang berkembang saat ini. Beberapa siswa juga memaknai pentingnya menjaga nilai - nilai pembelajaran Tarikh. Hal tersebut dijalaskan dalam wawancara yang dilakukan oleh peneliti.

Berdasarkan penjelasan guru dan beberapa siswa terkait dengan peran pembelajaran Tarikh dalam pelestarian budaya, peneliti menyimpulkan bahwa sebagai masyarakat berbudaya, baik siswa maupun guru sangat menganggap penting pendidikan Tarikh. Nilai - nilai edukasi yang dipakai dalam menerima budaya akan menjadikan siswa dan guru sadar tentang pengaruh - pengaruh yang akan di dapat kemudian hari. Banyaknya budaya yang berkembang maupun percampuran budaya yang ada menjadikan pendidikan penting untuk pelaksanaan pembelajaran Tarikh di sekolah.
Pembelajaran Tarikh berbasis kearifan lokal ini diharapkan guru dapat menjadikan karakter positif bagi siswa. Nilai edukasi yang ada dalam nilai - nilai pembelajaran Tarikh dijadikan sebagai alat filter hingga pelestarian budaya, sehingga diharapkan mampu memupuk karakter positif siswa yang dituangkan dalam kemampuan belajar. Kemampuan belajar siswa merupakan usaha yang guru bangun dalam proses belajar.

Berdasarkan penjelasan guru dan beberapa siswa mengenai motivasi siswa dalam pembelajaran Tarikh, peneliti menyimpulkan bahwa motivasi lisan yang diberikan guru tidak selalu diberikan dalam pembelajaran. Motivasi masih menjadi suatu usaha besar guru untuk meningkatkan kemampuan belajar siswa. Di samping itu, peneliti juga menemukan salah satu faktor kurangnya pemberian motivasi dalam pembelajaran, yakni jumlah jam pelajaran Tarikh. Jumlah jam pelajaran Tarikh untuk siswa hanya satu jam pelajaran dengan materi yang disampaikan lumayan banyak. Oleh sebab itu, guru menjadi terfokus pada penyampaian materi saja, tidak sampai pemberian motivasi.

Dalam pembelajaran Tarikh, salah satu upaya yang diajarkan sebagai alat perkembangan agama Islam dalam bidang pendidikan yakni materi mengenai Sejarah Kebudayaan Islam. Sejarah Kebudayaan Islam merupakan salah satu ruang lingkup dalam pembelajaran Tarikh. Dakum dan Mursyidatun Ni'mah (Ni'mah, 2018) dalam bukunya memaparkan terkait dengan materi materi yang terdapat dalam pembelajaran Tarikh kelas IX sebagai berikut.

BAB I sejarah masuknya Islam di Indonesia : pada bab pertama ini menjelaskan tentang kronologi sejarah masuknya Islam di Indonesia dengan cara penyebaran Islam di 
Indonesia serta bukti - bukti sejarah masuknya Islam di Indonesia. Dalam bab ini juga menjelaskan tentang peran Walisongo dalam menyebarkan Islam di Indonesia. Dan juga menjelaskan beberapa kerajaan Islam di wilayah Indonesia diantaranya Sumatra, Jawa, Kalimantan, Sulawesi, Maluku. Pada bab keempat ini terdapat keterkaitan dengan kearifan lokal di Daerah Istimewa Yogyakarta serta daerah - daerah penyebaran agama Islam di Indonesia. Hal ini merupakan tatanan nilai masyarakat di berbagai daerah di Indonesia yang diwariskan dari generasi ke generasi selajutnya sebagai kearifan lokal yang terkait dengan sistem kepercayaan masyarakat.

BAB II perkembangan budaya Islam di Indonesia : dalam bab ini menjelaskan tentang pengertian budaya Islam, ragam budaya di Indonesia serta ragam budaya Islam di Indonesia. Pada bab ini juga memuat tentang nilai - nilai budaya Islam di Indonesia. Hal ini berkaitan dengan kearifan lokal sebagai komponen penting dalam masyarakat, terutama sebagai alat yang mampu membangun masyarakat yang sesuai dengan karakter bangsa.

BAB III sejarah awal munculnya seni budaya Islam di Indonesia : pada bab ketiga ini berisikan materi tentang seni dan budaya Islam di Indonesia yang memuat tentang awal masuk tradisi dan upacara adat bernuansa Islami di Indonesia serta keistimewaan berbagai budaya yang bernuansa Islami di Indonesia. Bab ketiga ini juga menjelaskan tentang peran umat Islam di Indonesia dalam bidang budaya. Hal ini sesuai dengan pendidikan berbasis kearifan lokal yang menjadikan beberapa kearifan yang ada sebagai media, sarana, dan peraga dalam pembelajaran Tarikh.

BAB IV keragaman budaya Islam yang berkemajuan : bab keempat ini berisikan materi budaya Islam di Indonesia yang berkemajuan. Di dalamnya juga terdapat bentuk - bentuk keragaman budaya Islam di Indonesia yang berkemajuan serta nilai nilai budaya Islam yang berkemajuan. Hal ini sesuai dengan kearifan lokal melalui pembelajaran Tarikh yang dapat diadaptasi dengan kultur masa kini.

\section{Kearifan Lokal Dalam Pembelajaran Tarikh}

John Haba menjelaskan bahwa kearifan lokal merupakan kekayaan budaya serta pengetahuan yang ada pada masyarakat dan telah berkembang dari masa ke masa, sehingga terus mengalami perkembangan dan perubahan (Supriyanto, 2018). Kearifan lokal memiliki beberapa ciri yang menjadi dasar pandangan tentang keadaan yang terjadi di masyarakat. Bebebrapa diantara ciri - ciri tentang kearifan lokal peneliti temukan dalam pembelajaran Tarikh pada kelas IX di SMP Muhammadiyah 3 Yogyakarta. Pelaksanaan pembelajaran Tarikh berbasis kearifan lokal juga berjalan selaras dengan definisi tersebut. Kaitannya dengan ciri - cini kearifan lokal, peneliti menganalisis berdasarkan hasil penelitian sebagai berikut :

1) Kelestarian kearifan lokal hingga saat ini merupakan usaha suatu masyarakat untuk menjaga identitas dan peninggalan sejarah dari nenek moyang. Usaha tersebut mereka lakukan atas keniscayaan perlakuan oleh orang terdahulu. Hal tersebut menjadikan ciri khas dalam masyarakat. 
Masyarakat modern menjaga kearifan lokal berdasarkan sikap dan perilaku orang - orang disekitarnya.

Kearifan lokal terbentuk berdasarkan pengalaman. Bapak Supardiyono menjelaskan dalam pembelajaran dikelas, bahwa latihan soal yang berulang merupakan usahanya untuk pemperkuat ingatan siswa sebagai persiapan ujian. Bisa sebagai alat persiapan ujian sekolah, ujian berbasis komputer, hingga ujian nasional. Berdasarkan pengalaman guru Tarikh, dengan pemberian soal - soal latihan mampu meningkatkan kemampuan berfikir siswa. Hal tersebut peneliti tangkap sebagai salah satu ciri kearifan lokal yang terbentuk berdasarkan pengalaman guru.

2) Pembelajaran berbasis kearifan lokal pada kelas IX di SMP Muhammadiyah 3 Yogyakarta juga telah teruji selama bertahun tahun sebagai harapan sekolah untuk mewujudkan siswa beriman. Hal tersebut terumuskan dalam misi SMP Muhammadiyah 3 Yogyakarta. Dalam misi sekolah dijelaskan bahwa siswa diharapkan mampu menumbuhkan penghayatan dan pengalaman terhadap ajaran agama Islam melalui pembelajaran Iqro, tadarus Al - Qur'an dan sholat dhuhur berjamaah disekolah.

Kearifan lokal telah teruji selama bertahun - tahun. Pembelajaran Tarikh berbasis kearifan lokal berdasarkan misi sekolah berupa pengaitan materi pembelajaran sejarah kebudayaan Islam yang banyak ditemui dalam ayat -ayat suci $\mathrm{Al}$ - Qur'an. Dengan pembelajaran Tarikh, guru mampu menjadikannya sebagai contoh dalam pengaitan secara nyata bahwa firman Allah yang terkandung dalam $\mathrm{Al}-$ Qur'an relevan dengan materi pelajaran Tarikh. Tadarus yang dilakukan oleh siswa setiap harinya walau tidak hanya membaca ayat tentang pembelajaran Tarikh, namun diantara ayat - ayat yang terkait mampu guru jadikan sebagai pembahasan yang sesuai dengan materi pelajaran. Hal ini peneliti simpulkan sebagai kearifan lokal yang telah teruji seama bertahun - tahun di SMP Muhammadiyah 3 Yogyakarta.

3) Salah satu ciri kearifan lokal yakni mampu berkembang dan beradaptasi dengan kondisi dan sikap masyarakat. Kearifan lokal yang masih ada hingga saat ini banyak yang sudah dimodifikasi dan dikolaborasikan dengan sentuhan modernisme yang berkembang sesuai dengan tuntutan zaman. Kearifan lokal tidak pernah kehilangan jati dirinya seiring majunya peradaban. Namun kini kearifan lokal menjadi lebih memiliki nilai - nilai yang tinggi atas kesadaran pentingnya pelestarian kearifan tersebut.

Kearifan Lokal Dapat Diadaptasi Dengan Kultur Masa Kini. Pelaksanaan pembelajaran model diskusi kelompok dilaksanakan di kelas IX D. Kelas tersebut merupakan salah satu kelas unggulan dengan program reguler. Dalam pembelajaran siswa sudah menerapkan pembelajaran berbasis kearifan lokal. Pertama, hal tersebut terbukti dengan sikap gotong royong yang timbul dari pembelajaran model diskusi kelompok. Kedua, pembelajaran dengan diskusi kelompok mampu menumbuhkan keterampuilan berfikir siswa. Siswa mampu mengetahui contoh - contoh dari materi Tarikh tentang materi sejarah awal munculnya seni budaya Islam di Indonesia dengan lebih beragam dan mampu memahami definisi definisi dengan caranya sendiri. Ketiga, siswa kelas IX D dalam pembelajaran sudah melaksanakan dengan sikap menghargai rekan kelompok lain. Hal tersebut terbukti berdasarkan hasil pengamatan 
kelas oleh peneliti, saat masing - masing kelompok memulai presentasi, maka kelompok lain memperhatikan temannya dan mempersiapkan masukan atau pertanyaan terkait materi yang disampaikan.

4) Terciptanya kebiasaan dalam masyarakat timbul dari perilaku suatu lembaga atau kebiasaan hidup masyarakat. Kaitannya dengan hasil penelitian pada kelas IX di SMP Muhammadiyah Yogyakarta, peneliti mendapatkan hasil bahwa logat bahasa siswa masih banyak yang kurang sopan terhadap guru. Siswa masih banyak yang berbicara dengan guru menggunakan bahasa jawa "ngoko" seperti cara berbicara dengan teman. Hal tersebut didapatkan peneliti pada hasil penelitian kelas yang dilakukan 14 November 2019 di sebagian kelas IX.

Dalam berkomunikasi di kelas, siswa kurang memperhatikan tata bahasa yang dipergunakan. Hal ini merupakan faktor pengaruh sosial tempat dimana siswa tinggal. Kurangnya pemahaman siswa dalam penerapan bahasa yang sopan untuk dipergunakan dalam percakapan kepada yang lebih tua diikuti dengan sikap guru yang kurang memperhatikan akan hal itu menjadikan siswa kurang sadar akan pentingnya kesopanan dalam berbahasa. Peneliti mendapatkan hasil bahwa dalam komunikasi dikelas guru sangat merespon baik semua percakapan siswa. Namun, saat siswa memakai bahasa yang kurang sopan, guru tidak lantas direspon guru untuk ditegur dan diberi nasihat.

Kearifan Lokal Terdapat Dalam Praktek Pada Kelembagaan Dan Kehidupan Mayarakat. Dalam berkomunikasi di kelas, siswa kurang memperhatikan tata bahasa yang dipergunakan. Hal ini merupakan faktor pengaruh sosial tempat dimana siswa tinggal. Kurangnya pemahaman siswa dalam penerapan bahasa yang sopan untuk dipergunakan dalam percakapan kepada yang lebih tua diikuti dengan sikap guru yang kurang memperhatikan akan hal itu menjadikan siswa kurang sadar akan pentingnya kesopanan dalam berbahasa. Peneliti mendapatkan hasil bahwa dalam komunikasi dikelas guru sangat merespon baik semua percakapan siswa. Namun, saat siswa memakai bahasa yang kurang sopan, guru tidak lantas direspon guru untuk ditegur dan diberi nasihat.

\section{5) Kearifan Lokal Bersifat Dinamis.} Berdasarkan hasil wawancara dengan Bapak Supardiyono diatas, dapat diketahui bahwa cara guru untuk menumbuhkan pembelajaran Tarikh salah satunya dengan usaha membangun keyakinan siswa. Materi Tarikh yang sebagian bersifat keabstrakan mengharuskan guru untuk menyampaikan pembelajaran dengan pemberian contoh serta praktek agar usahanya dapat terrealisasikan. Pembangunan kepercayaan kepada siswa, erat kaitannya dengan antusias siswa dalam belajar. Maka hal yang mendasari siswa agar terbentuk keyakinan terhadap pembelajaran harus dimulai dengan pemberian stimulus agar siswa antusias terhadap pembelajaran Tarikh.

Banyak usaha yang diperlukan dalam untuk mengimplementasikan materi pelajaran Tarikh. Hal itu menjadikan tantangan tersendiri bagi guru untuk meningkatkan kreatifitas dan inovasi dalam pembelajaran. Dalam semua materi pembelajaran, memang guru harus memberikan contoh sebagai wujud nyata pentingnya sebuah materi pelajaran. Disamping itu, perwujudan dalil - dalil aqli yang benar, shahih, dan valid ketika guru mampu merealisasikan dengan keadaan masa kini maka anak akan antusias dalam belajar. 
6) Berdasarkan hasil penelitian kelas dan hasil wawancara yang dilakukan peneliti, didapatkan hasil bahwa siswa telah mampu memfilter budaya maupun adat yang berkembang di sekitarnya. Berdasarkan wawancara kepada Muhammad Ikhsan dan Marcello peneliti mendapatkan hasil bahwa para siswa telah menyadari bahwa budaya yang berkembang di masyarakat saat ini telah mendapat campur aduk dengan budaya lain. Mereka sadar bahwa sebagai siswa yang bersekolah di wilayah berbudaya mereka harus mampu menyaring budaya yang ada. Baik budaya lokal dengan budaya asing, maupun budaya Islam dengan budaya non Islam. Siswa kelas IX di SMP Muhammadiyah Yogyakarta menjadi kearifan lokal tersendiri berdasarkan jenis kearifan lokal dalam bentuk ide. Mereka mampu menjadi filter atas perkembangan budaya yang ada di masyarakat.

Berdasarkan beberapa ciri - ciri kearifan lokal dalam pembelajaran yang peneliti dapat dalam penelitian, faktor yang sangat dominan dalam pelaksanaan pembelajaran berbasis kearifan lokal adalah pembelajaran yang dikontekstualisasikan guru atas kebiasaan atau budaya yang berkembang dimasyarakat. Cara guru mengkontekekstualisasikan dengan cara pemberian contoh - contoh yang berkaitan pada materi Tarikh dengan fenomena yang terjadi di masyarakat. Dengan pemberian contoh, guru telah berusaha untuk membuka pemahaman siswa terhadap materi pembelajaran Tarikh. Materi - materi pembelajaran Tarikh banyak dijumpai dalam kehidupan saat ini, terutama pada materi sejarah kebudayaan Islam di Indonesia. Pembelajaran Tarikh menjadi alat dalam pembelajaran sebagai pengontrol kebiasaan yang tumbuh dan berkembang di masyarakat. Terlebih bekal bagi siswa kelas IX untuk memahaminya sebagai masyarakat yang berakal dan beragama. Pelajaran Tarikh merupakan pondasi yang dibangun guru dengan usaha sadar agar mampu mengantar siswanya menjadi berkarakter dan berbudaya.

\section{KESIMPULAN}

Pelaksanaan pembelajaran Tarikh di SMP Muhammadiyah 3 Yogyakarta masih dominan menggunakan metode ceramah. Disamping itu, pelaksanaan pembelajaran Tarikh sesuai dengan kearifan lokal diantaranya ialah pertama, kearifan lokal terbentuk berdasarkan pengalaman dalam bentuk pelaksanaan ulangan harian Tarikh sebagai persiapan ujian. Pelaksanaan ulangan harian merupakan pengalaman guru agar siswa terbiasa dengan latihan soal - soal sebagai persiapan siswa dalam menghadapi berbagai macam ujian. Kedua, kearifan lokal telah teruji selama bertahun - tahun dalam bentuk pembiasaan tadarus $\mathrm{Al}$ - Qur'an yang tertuang dalam misi sekolah. Dimana dalam pelaksanaan tadarus terdapat beberapa kandungan ayat yang dipelajari dalam pembelajaran Tarikh. Ketiga, kearifan lokal dapat diadaptasi dengan kultur masa kini dalam bentuk pemberian tugas dengan menggunakan metode diskusi kelompok yang mampu menumbuhkan sikap gotong royong. Kempat, kearifan lokal terdapat dalam praktek pada kelembagaan dan kehidupan masyarakat yakni pada kebiasaan siswa dalam menggunakan berbahasa Jawa dalam proses pembelajaran yang sesuai dengan masyarakat tempat mereka tinggal. Kelima, kearifan lokal bersifat dinamis dalam bentuk penanaman keyakinan siswa pada pembelajaran Tarikh yang didalamnya terdapat banyak materi yang bersifat keabstrakan. Penanaman keyakinan siswa dengan cara guru menjelaskan dalil shohih 
yang terkait serta memberi contoh sebagai implementasi materi. Keenam, kearifan lokal terkait dengan pembangunan kepercayaan masyarakat yakni melalui penyaringan budaya yang merupakan salah satu tujuan pembelajaran Tarikh. Dengan pembelajaran Tarikh siswa mampu menyaring budaya asing dengan budaya lokal, maupun budaya Islam dengan budaya non Islam. Dan pelaksanaan pembelajaran Tarikh selaras dengan fungsi kearifan lokal sebagai pengembangan sumber daya manusia, sebagai konservasi serta pelestarian sumber daya alam, dan sebagai pengembangan kebudayaan serta ilmu pengetahuan, petuah, kepercayaan, sastra dan pantangan bermakna sosial yang terlihat pada upacara suatu komunitas atau kerabat yang bermakna etika serta moral politik.Faktor pendukung pembelajaran Tarikh pada kelas IX di SMP Muhammadiyah 3 Yogyakarta ialah pertama, fasilitas dan media belajar yang sangat memadahi. Kedua, kesadaran siswa akan pentingnya menjaga sejarah dan budaya. Faktor penghambat pembelajaran Tarikh pada kelas IX di SMP Muhammadiyah 3 Yogyakarta ialah pertama, suasana kelas yang kurang mendukung, banyaknya materi pelajaran Tarikh, kurangnya motivasi belajar siswa. Di samping itu, guru memiliki upaya untuk mengatasi hambatan - hambatan tersebut. Pertama, guru senantiasa mengatur penataan kelas sebelum pembelajaran. Kedua, guru harus selalu berusaha untuk memberikan pembelajaran yang lebih kreatif dan invatif. Ketiga, guru senantiasa mengingatkan siswa kelas IX untuk bersungguh - sungguh dalam menerima pelajaran karena terbatasnya waktu sebelum persiapan ujian nasional.

\section{DAFTAR PUSTAKA}

Arif, M. (2015). Islam, Kearifan Lokal Dan Kontekstualisasi Pendidikan. Al-Tahrir, Vol. 15, No. 1, 67-90.

Al-Quraibi, I. (2009). Tarikh Khulafa. Jakarta: Qisthi Press.

Hamdani. (2011). Strategi Belajar Mengajar. Bandung: Pustaka Setia.

Khilmiyah, A. (2016). Metode Penelitian Kualitatif. Yogyakarta: Samudra Biru.

Mardhiyah. (2016). Efektivitas Penggunaan Media Pembelajaran Audio Visual Terhadap Motivasi Belajar Sejarah Kebudayaan Islam Pada Siswa Kelas VIII MTs Negeri Gajah Demak Tabun Ajaran 2016/2017. Skripsi, 44-45. (Online). Retrieved from: http:/ / eprints.walisongo.ac.id/ 7594/1/133111036.pdf.

Ni'mah, D. d. (2018). Pendidikan Tarikh SMP Muhammadiyah. Jakarta: Gramasurya.

Nugraha, M. T. (2019). Sejarah Pendidikan Islam. Yogyakarta: Diandra Kreatif.

Sugiyono. (2010). Metode Penelitian Pendidikan. Bandung: Alfabeta.

Supiana. (2017). Metodologi Studi Islam. Bandung: Remaja Rosdakarya.

Supriyanto, M. I. (2018). Islam And Local Wisdom. Yogyakarta: Deepublish.

Ramdhani, M. A. (2014). Perbandingan Strategi Pembelajaran Teacher Centered Learning Dengan Student Centered Learning Terhadap Hasil Belajar Pada Mata Pelajaran Tarikh Siswa Kelas VIII SMP Muhammadiyah 4 Surakarta. (Online). Retrieved from: http:/ / eprints. ums.ac.id/30865/1/03._HALAMAN_D EPAN.pdf.

Setyawan, D., \& Arumsari, A. D. (2019). Pengembangan Media Pembelajaran Audio Visual Pada Mata Pelajaran Sejarah Kebudayaan Islam (SKI). Educultural: International Journal of Education, Culture and Humanities, Vol. 1, No. 2, 110.

Rofik, Rofik. (2015). Nilai Pembelajaran Sejarah Kebudayaan Islam Dalam Kurikulum 
Madrasab. Jurnal Pendidikan Agama

Islam, Vol. XII, No. 1, 15-30. 